$\xi=\mathbf{p}$

\title{
Non-thermal microwave radiation-induced brain tissue dehydration as a potential factor for brain functional impairment
}

\author{
Anna Nikoghosyan, Armenuhi Heqimyan, Sinerik Ayrapetyan* \\ UNESCO Chair-Life Sciences International Postgraduate Educational Center Yerevan, Armenia \\ *Corresponding author E-mail:info@biophys.am
}

\begin{abstract}
Based on our previous finding that metabolically controlled cell hydration is sensitive to the changes of physicochemical properties of cell aqua medium, which take place upon the effect of weak physical signals, including microwaves with non-thermal intensity (NT MW), it has been hypothesized that cell aqua medium serves as a primary target for NT MW effect on brain tissue. To elucidate the nature of the metabolic pathway through which the effect of NT MW-induced changes of physicochemical properties of cell aqua medium modulate cell hydration, the effects of intraperitoneal (IP) injection of PS treated by NT MW on brain tissue hydration, ${ }^{45} \mathrm{Ca}^{2+}$ uptake, $\left[{ }^{3} \mathrm{H}\right]$-ouabain binding with cell membrane and intracellular cyclic nucleotides have been studied. The obtained data indicate that PS treated by NT MW through the activation of high affinity ouabain receptors in membrane stimulates cAMP-dependent $\mathrm{Na}^{+} / \mathrm{Ca}^{2+}$ exchange in reverse mode $(\mathrm{R})$, which leads to brain tissue hydration in healthy (young) and dehydration in non-healthy (old) rats.

As NT MW radiation-induced activation of $\mathrm{R} \mathrm{Na}^{+} / \mathrm{Ca}^{2+}$ exchange leads to the increase of intracellular $\mathrm{Ca}^{2+}\left(\left[\mathrm{Ca}^{2+}\right]_{\mathrm{i})}\right.$, it is considered as a potential factor leading to the brain functional impairment, especially when brain metabolic activity is depressed (e.g. during aging).
\end{abstract}

Keywords: Brain Cortex; Cell Hydration; Cyclic AMP; Intracellular $\mathrm{Ca}^{2+}$; Microwave Radiation.

\section{Introduction}

More than three decades have passed since the discovery that nonthermal microwaves (NT MW) with less intensity than thermal threshold are characterized by the biological effects on living objects [1], [2], [3], [4], [5].

Although there is a great number of data on the significant effects of NT MW on the enzymatic activity in brain tissues and immune properties of organism [6], [7], the nature of primary metabolic target(s), through which NT MW effects are realized, is not clear yet. Since the phenomenon of the biological effect of NT MW cannot be explained from the point of classic thermodynamics [8], it is clear that the electron, which has high charge to mass ratio could serve as a target for such an extremely low energy impact [9], [10].

Since the water content of head skin and sub-skin tissues has high sorption properties for NT MW, the energy of the latter cannot reach to brain tissue. Considering the fact that the valence angle of water molecules, determining physicochemical properties of water, is extra-sensitive to non-ionizing radiation, including NT MW, [11], [12], [13], the water content of skin and sub-skin tissue has been suggested as a primary target for the biological impact of NT MW on organisms [4], [13].

Our previous study has shown that when MW radiation penetrates into rat's brain through brain skin (containing $73 \%$ water), specific absorption rate(SAR) equals to $5,8 \mathrm{~mW} / \mathrm{cm}^{2}$, and when it reaches to brain tissues, SAR is $<1,63 \mathrm{~mW} / \mathrm{cm}^{2}$. This value of SAR has dose-dependent modulation effect on brain tissue hydration [14]. However, the nature of the messenger through which NT MW modulates the structural changes in cell aqua medium and metabolically controls brain tissue hydration has not been elucidated yet.

Based on the facts that in living cells: a) water, being a common medium for intracellular reactions, determines the metabolic activity of cells, b) intracellular osmotic pressure exceeds the extracellular one, c) cell membrane has high permeability for water [15], [16] and d) water molecule dissociation and reactive oxygen species (ROS) are increased after NT MW radiation, it is suggested that water molecules and their dissociation products are primary messengers for NT MW effect on cell metabolism. To check this hypothesis the effects of intraperitoneal (IP) injection of physiological solution (PS) preliminarily treated by NT MW on tissue dehydration, $\left[{ }^{3} \mathrm{H}\right]$-ouabain binding with membrane, ${ }^{45} \mathrm{Ca}^{2+}$ uptake and intracellular content of cyclic nucleotides in rats' brain cortex have been studied.

\section{Materials and methods}

\subsection{Animals}

All procedures performed on animals were carried out following the protocols approved by Animal Care and Use Committee of Life Sciences International Postgraduate Educational Centre (LSIPEC, Yerevan, Armenia).

Experiments were performed on 273 adult and 27 old albino rats. They were regularly examined, kept under control of the veterinarians in LSIPEC and reserved in a specific pathogen-free animal room under optimum conditions of $12 \mathrm{~h} \mathrm{light/dark} \mathrm{cycles,} \mathrm{at} \mathrm{tem-}$ perature of $22 \pm 2^{\circ} \mathrm{C}$, with a relative humidity of $50 \%$ and were fed ad libitum on a standard lab chow and water. 


\subsection{Chemicals}

Tyrode's PS containing (in $\mathrm{mM}$ ) $137 \mathrm{NaCl}, 5.4 \mathrm{KCl}, 1.8 \mathrm{CaCl}_{2}$, $1.05 \mathrm{MgCl}_{2}, 5 \mathrm{C}_{6} \mathrm{H}_{12} \mathrm{O}_{6}, 11.9 \mathrm{NaHCO}_{3}$, and $0.42 \mathrm{NaH}_{2} \mathrm{PO}_{4}$, adjusted to $\mathrm{pH} 7.4$ with $\mathrm{NaOH}$ was used. In order to receive $50 \% \mathrm{PS}$, $68.5 \mathrm{mM}$ of $\mathrm{NaCl}$ was replaced with $2 \mathrm{M}$ of non-metabolizing substance - mannitol dissolved in PS for maintaining the osmolarity of the solution. $\mathrm{K}^{+}$-free solution had an excess of $5.4 \mathrm{mM} \mathrm{NaCl}$ above normal. All chemicals were obtained from "Medisar" Industrial Chemical Importation Company (Yerevan, Armenia) $\left[{ }^{3} \mathrm{H}\right]$-ouabain with specific activity $(25.34 \mathrm{Ci} / \mathrm{mM})$ and nonradioactive ouabain (PerkinElmer, Massachusetts, USA) from 10${ }^{11} \mathrm{M}$ to $10^{-4} \mathrm{M}$ concentrations dissolved in PS were used for IP injections and tissue incubation.

\subsection{Source of MW radiation}

Device for MW therapy "Artsakh-04M" (Quantum Medicine Association Coloyaro-2000, Moscow, Russian Federation) was used as MW source. It consists of a microprocessor managing system of solid-state generation of MW in the ranges of $90-160 \mathrm{GHz}$ with amplitude modulation with $0-99 \mathrm{~Hz}$ pulse-rate. In experiments a noise with frequency spectrum of $90-160 \mathrm{GHz}$ modulated with $4 \mathrm{~Hz}$ was used. The device has a dielectric antenna, the tip of which has a diameter of $5 \mathrm{~mm}^{2}$. At the tip of antenna MW is released with SAR=1.49 $\mathrm{mW} / \mathrm{g}$. The energy of MW absorbed by 1 ml PS was estimated by a high precision differential calorimetric device "Biophys MWD-001" (LSIPEC, Yerevan, Armenia) [17] SAR was measured according to the following equation: SAR = $\mathrm{C}_{\mathrm{PS}} \Delta \mathrm{T} / \Delta \mathrm{t}$, where $\mathrm{C}$ is PS specific heating capacity, $\Delta \mathrm{T}-$ the change of absolute temperature, and $\Delta \mathrm{t}$ - exposure time.

In the experiments the temperature of $1 \mathrm{ml}$ PS, which was initially $20^{\circ} \mathrm{C}$, raised by $0.219^{\circ} \mathrm{C}$ after treated by NT MW for $10 \mathrm{~min}$, which corresponds to $\mathrm{SAR}=1.49 \mathrm{~mW} / \mathrm{g}$. As the volume of NT MW-treated PS used in the experiments was $30 \mathrm{ml}$, having surface of $10 \mathrm{~cm}^{2}$ and $3 \mathrm{~cm}$ thickness, SAR by which $30 \mathrm{ml}$ PS was treated was considered $\sim 0.05 \mathrm{~mW} / \mathrm{g}$.

Sham and MW treatments of PS used for in vivo (IP injection) and in vitro experiments were performed by the following way: the tip of the dielectric antenna was inserted in a tube containing $30 \mathrm{ml}$ PS having $10 \mathrm{~cm}^{2}$ surface and $3 \mathrm{~cm}$ thickness, sham and MW treatments of PS were carried out by exposing PS for $10 \mathrm{~min}$ at the same conditions and the device was switched off and on, respectively.

To stabilize the initial temperature of $30 \mathrm{ml}$ PS treated by NT MW, the tube with $30 \mathrm{ml}$ PS was kept in water bath for 10 min with the temperature of $20^{\circ} \mathrm{C}$. Then NT MW-treated PS was used both for in vivo (IP injection) and in vitro (bathing medium of brain slices) experiments.

\subsection{Tissue preparation}

It is well known that anesthetics with different chemical and pharmacological profiles significantly affect metabolic processes, which play an important role in regulation of cell volume [18], [19]. Therefore, in present experiments animals were sharply immobilized by freezing method (dipping their noses into liquid nitrogen for 3-4 sec) and decapitated [20]. After such a procedure the full absence of somatic reflexes on extra stimuli was recorded. Tissues of cortex were isolated (10 samples from each animal); the weight of each sample was from 50 to $70 \mathrm{mg}$. For each experimental group three animals were chosen. All data were received from three independent experiments.

\subsection{Definition of water content of brain tissues}

Water content of brain tissue was determined by traditional "tissue drying" method [21]. After measuring the wet weight (w.w.) of brain tissue it was dried in oven (Factory of Medical Equipment, Odessa, Ukraine) for $24 \mathrm{~h}$ at $105^{\circ} \mathrm{C}$ for determination of dry weight (d.w.). The quantity of water in $1 \mathrm{~g}$ of d.w. tissue was counted by the following equation: (w.w.-d.w.)/d.w.

\subsection{Counting of $\left[{ }^{3} \mathrm{H}\right]$-ouabain receptors in membrane}

To estimate the number of $\mathrm{Na}^{+} / \mathrm{K}^{+}$-ATPase molecules in membrane, the number of $\left[{ }^{3} \mathrm{H}\right]$-ouabain molecules binding with cell membrane was counted. In vivo experiments $\left[{ }^{3} \mathrm{H}\right]$-ouabain was intraperitoneally injected to animals. After $30 \mathrm{~min}$ animals were sacrificed and brain slices were dissected and incubated in $100 \mathrm{ml}$ ouabain-free PS. To remove surface-adherent and extracellular tracer, brain slices were washed fivefold; each wash was about $5 \mathrm{~min}$ in duration, in normal (ouabain-free) PS. After determination of wet and dry weights of samples, they were homogenized in 50 $\mu \mathrm{l}$ of $68 \% \mathrm{HNO} 3$ solution. Then $2 \mathrm{ml}$ of Bray's scintillation fluid was added and chemoluminescence of samples was quantified with 1450-MicroBeta liquid scintillation counter (WallacOy, Tur$\mathrm{ku}$, Finland). The number of ouabain molecules binding with cell membranes was defined per mg of dry weight of samples. The ouabain concentration injected to the animal was adjusted to animal body weight $\left(10^{-x} \mathrm{M} / \mathrm{g}\right.$ of animal weight). The volume of the injected PS was also adjusted to the weight of animals $(0.2 \mathrm{ml} / \mathrm{g}$ of animal weight). Respective concentrations of ouabain used in vivo experiments were added in PS where brain slices were bathing.

\subsection{Measurement of ${ }^{45} \mathrm{Ca}^{2+}$ uptake}

${ }^{45} \mathrm{Ca}^{2+}$ uptake was measured by the following way: $0.0115 \mathrm{mM}$ $\mathrm{CaCl}_{2}$ from $1.8 \mathrm{mM}$ was substituted by radioactive ${ }^{45} \mathrm{Ca}^{2+}(11.2$ $\mathrm{mCi} / \mathrm{l})$ in PS. Animals were intraperitioneally injected with ${ }^{45} \mathrm{Ca}^{2+}$ (with $0.187 \mathrm{mCi} / \mathrm{g}$ radioactivity of body weight) dissolved in sham- and NTMW-treated PS. After 30 min animals were decapitated and brain samples were incubated for $30 \mathrm{~min}$ in PS (as a control) and PS once containing $10^{-9} \mathrm{M}$ and once $10^{-4} \mathrm{M}$ ouabain. Then all samples were dried in thermostat during $24 \mathrm{~h}$ at $105^{\circ} \mathrm{C}$. The quantity of ${ }^{45} \mathrm{Ca}^{2+}$ uptake by brain slices was expressed by $\mathrm{Cpm} / \mathrm{mg}$ d. w.

\subsection{Determination of cAMP content in the samples}

Determination of cAMP content in the samples was performed according to the cyclic AMP ${ }^{125}$ I] RIA KIT manual (PerkinElmer Life sciences, Inc.) (http://www.perkinelmer.com/labsolutions//resources/docs/MAN cAMPRadioimmunoassayKit.pdf). Precipitation of proteins from plasma or tissues has been accomplished with trichloroacetic acid (TCA). Frozen tissue samples were homogenized at $4^{\circ} \mathrm{C}$ with $6 \%$ TCA to make a $1 \mathrm{~mL} 10 \%$ (w/v) homogenate. Equal volume of cold $10 \%$ TCA was added supernatants. TCA extracts were centrifuged at $2,500 \mathrm{x}$ g at $4^{\circ} \mathrm{C}$ for $15 \mathrm{~min}$. The supernatant was collected and extracted 4 times with $5 \mathrm{x}$ volume of water-saturated ether. After this the ether phase was discarded. Later, the samples were placed in a water bath at $70-80^{\circ} \mathrm{C}$ and evaporated to dryness under a stream of air. The residue was dissolved in Assay Buffer and $100 \mu \mathrm{L}$ of this solution was used directly in the Assay. The counting of the samples was performed by Wallac 1450 liquid scintillation counter (WallacOy, Turku, Finland). The concentration of cAMP in the samples was determined by interpolation from the standard curve.

\subsection{Determination of cGMP content in the samples}

Determination of cGMP content in the samples was performed according to the cyclic GMP $\left[{ }^{125}\right.$ I] RIA KIT manual (PerkinElmer Life sciences, Inc.) (http://www.perkinelmer.com/labsolutions/resources/docs/MAN_NEX133.pdf). Precipitation of proteins from plasma or tissues has been accomplished with TCA. Frozen tissue samples were homogenized at $4^{\circ} \mathrm{C}$ with $6 \%$ TCA. Samples were centrifuged at $2,500 \mathrm{x} \mathrm{g}$ at $4^{\circ} \mathrm{C}$ for $15 \mathrm{~min}$. The supernatant was collected and extracted 4 times with $5 \mathrm{ml}$ portions of water-saturated ether. After this the ether phase was discarded. Later, the samples were placed in a water bath at $70-80^{\circ} \mathrm{C}$ and 
evaporated to dryness under a stream of air. The residue was dissolved in Assay Buffer and $100 \mu \mathrm{L}$ of this solution was used directly in the Assay. The counting of the samples was performed by Wallac 1450 liquid scintillation counter (WallacOy, Turku, Finland). The concentration of cGMP in the samples was determined by interpolation from the standard curve.

\subsection{Statistic analysis}

Microsoft Excel and Sigma-Plot (Version 8.02A, NY, USA) were used for data analyses. Significance in comparison with the sham group was calculated with Student's paired t-test with the following symbols $(* \mathrm{p}<0.05 ; * * \mathrm{p}<0.01 ; * * * \mathrm{p}<0.001)$.

\section{Results}

Our previous study has shown that the direct brain radiation of 4Hz-modulated $90-160 \mathrm{GHz}$ NT MW leads to dehydration in head skin and brain tissues (cortex, sub-cortex and cerebellum) of rats. In the same study it has been shown that the incubation of snail single neuron in $4 \mathrm{~Hz}-$ modulated and $90-160 \mathrm{GHz}$ NT MW-treated PS brings to neuronal shrinkage [14]. However, the nature of the metabolic mechanism responsible for the changes of tissue hydration needs to be elucidated.

It is known that among numerous metabolic mechanisms regulating the cell, $\mathrm{Na}^{+} / \mathrm{K}^{+}$-ATPase (working molecule of $\mathrm{Na}^{+} / \mathrm{K}^{+}$pump) has a central role. In neurons there are three identified isoforms of $\mathrm{Na}^{+} / \mathrm{K}^{+}$-ATPase $\alpha$ catalytic subunit having different functional properties and affinities to ouabain: $\alpha_{1}$ (low affinity) and $\alpha_{2}$ (middle affinity) isoforms are involved in the processes of transporting $\mathrm{Na}^{+}$and $\mathrm{K}^{+}$and are sensitive to high concentrations of ouabain (from $10^{-8} \mathrm{M}$ to $10^{-4} \mathrm{M}$ ), while $\alpha_{3}$ (high affinity) is not involved in these processes and has only signaling function and serves as a gate for intracellular signaling system of cell [22], [23].

In order to elucidate the individual sensitivities of the above mentioned isoforms of $\mathrm{Na}^{+} / \mathrm{K}^{+}$-ATPase to NT MW, in the first series of our experiments the impact of NT MW radiation on dosedependent ouabain-induced brain cortex tissue hydration has been studied. As it can be seen in Fig.1, NT MW radiation brings to brain cortex tissue dehydration in the control groups of rats, which are intraperitoneally injected by ouabain-free PS, (compare black and white points on ordinate).

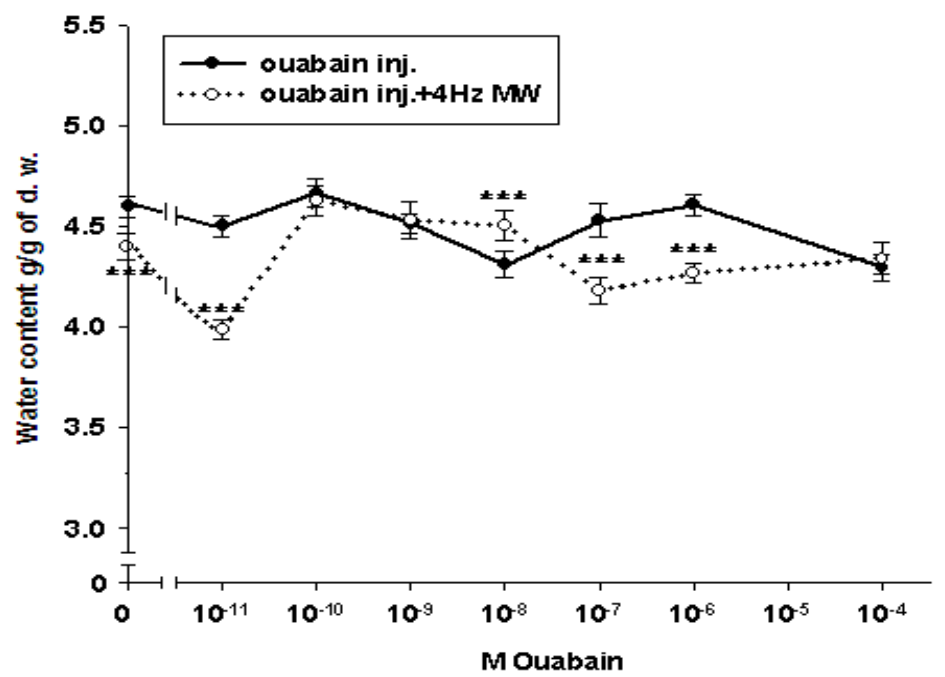

Fig. 1: Dose-Dependent Effect of Ouabain on Water Content in Brain Cortex of the Investigated Animals. The Continuous Line Presents the Data on Sham PS Injection (PS + Ouabain), While the Dash Line Presents the Data on NT MW-Treated PS + Ouabain Injection. Ordinates Indicate the Mean Value of Water Content in Tissues (G/G of D.W.), Abscissas Indicate $\left[{ }^{3} \mathrm{H}\right]$-Ouabain Concentrations in Mol (M). Each Point on Lines Represents the Mean and \pm SEMof Tissue Samples from Three Independent Experiments. The Number of Cortex Slices Is 90 . The Symbol (***) Indicates P<0.001. The Number of Adult Animals Used for the Experiment Is 144.

Different doses of ouabain under NT MW radiation lead to the pronounced effects of tissue hydration: low $\left(10^{-11} \mathrm{M}\right)$ and high $\left(10^{-7} \mathrm{M}\right.$ and $\left.10^{-6} \mathrm{M}\right)$ concentrations of ouabain lead to tissue dehydration, while $10^{-8} \mathrm{M}$ ouabain leads to tissue hydration. Thus, the presented data allow us to conclude that $\mathrm{SAR}=0.05 \mathrm{~mW} / \mathrm{g}$ is able to stimulate brain cortex tissue dehydration. As NT MW penetration into biological tissues is less than one millimeter, its direct effect on animal's brain can be explained by NT MW-induced changes of physicochemical properties of water components of skin and sub-skin tissues [4], [14]. To check this suggestion in the next series of experiments the effects of IP injection of NT MW-treated PS on brain cortex hydration in adult and old animals have been studied. As it can be seen in Fig. 2, in adult animals, after IP injection of sham-treated PS, hydration in brain cortex tissue is observed, while in old ones the similar injection leads to the pronounced brain cortex tissue dehydration. In both groups of animals IP injection of NT MW-treated PS leads to brain cortex tissue hydration. These data indicate that there are different mechanisms responsible for stress (PS injection)-induced and NT MW-induced tissue hydration.

It is known that $\mathrm{Na}^{+} / \mathrm{K}^{+}$pump-induced $\mathrm{Na}^{+}$gradient on membrane serves as an energy source for a number of secondary ionic trans- porters, including $\mathrm{Na}^{+} / \mathrm{Ca}^{2+}$ and $\mathrm{Na}^{+} / \mathrm{H}^{+}$exchangers having crucial roles in regulation of intracellular $\mathrm{Ca}^{2+}\left(\left[\mathrm{Ca}^{2+}\right]_{\mathrm{i}}\right)$, $\mathrm{pH}$ level as well as in regulation of cell metabolic activity. Therefore, in order to elucidate the possible role of $\mathrm{Na}^{+}$gradient on membrane in realization of dehydration effect of NT MW-treated PS on cortex tissue, the effect of NT MW-treated PS on cortex tissue hydration has been studied in the conditions where cortex tissue slices are incubated in PS containing $50 \% \mathrm{Na}^{+}$in both $20^{\circ} \mathrm{C}$ and $7{ }^{\circ} \mathrm{C}$ mediums. The data presented in Fig. 3 show that the incubation of brain cortex slices in NT MW-treated PS containing $100 \% \mathrm{Na}^{+}$at $20^{\circ} \mathrm{C}$ (Fig. 3A) increases tissue hydration, while the same procedure at $7^{\circ} \mathrm{C}$ (Fig. 3B) has a pronounced dehydration effect. It is known that the decrease of extracellular concentration of $\mathrm{Na}^{+}\left(\left[\mathrm{Na}^{+}\right]_{\mathrm{o}}\right)$ leads to the increase of $\left[\mathrm{Ca}^{2+}\right]_{\mathrm{i}}$ by activating $\mathrm{Na}^{+} / \mathrm{Ca}^{2+}$ exchange in reverse mode ( $\mathrm{R} \mathrm{Na}^{+} / \mathrm{Ca}^{2+}$ exchange) [26]. As $\mathrm{Na}^{+} / \mathrm{Ca}^{2+}$ exchange functions in stoichiometry of $3 \mathrm{Na}^{+}: 1 \mathrm{Ca}^{2+}$, it is predicted that $50 \%$ $\left[\mathrm{Na}^{+}\right]_{0}$ PS should lead to brain tissue dehydration unlike PS containing $100 \%\left[\mathrm{Na}^{+}\right]_{0}$ which brings to tissue hydration. As it can be seen in Fig. 3, $50 \% \mathrm{Na}^{+}$PS both at $20^{\circ} \mathrm{C}$ and $7^{\circ} \mathrm{C}$ has dehydration effect on brain cortex tissues. 


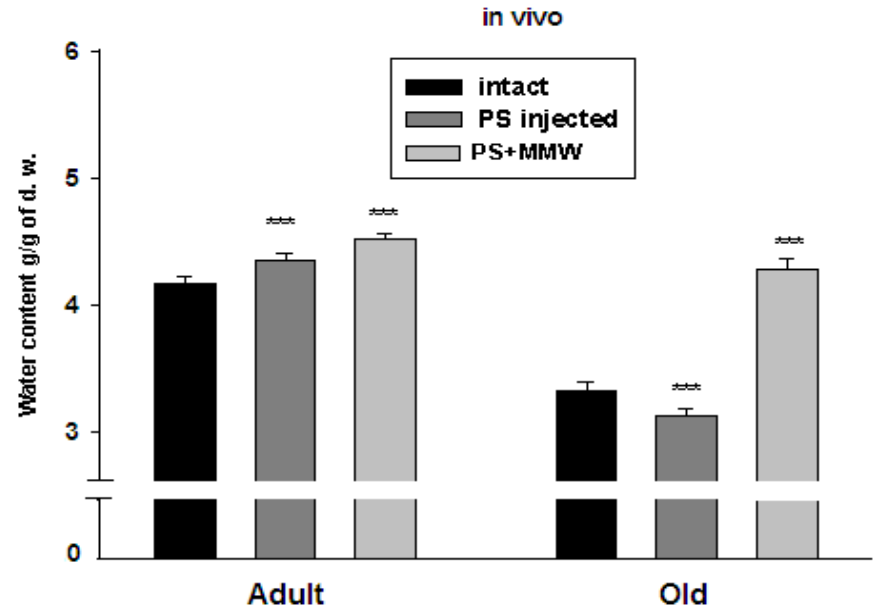

Fig. 2: The Changes of Water in Brain Cortex Tissue of Adult and Old Animals in Vivo Experiments in Intact State, After IP Injections of Sham- and NT MW-Treated PS. Ordinates Indicate the Mean Value of Water Content in Tissues (G/G of D.W.). Data of Each Pair of Bars are compared with Intact Data. Each Bar Represents the Mean and \pm SEM Of Water Content in Tissues (G/G. of D.W.) From Three Independent Experiments.The Number of Slices of Cortex Is 90. The Symbol (***) Indicates P<0.001. 27 Adult and 27 Old Animals Have Been Used for the Experiment.

in vitro
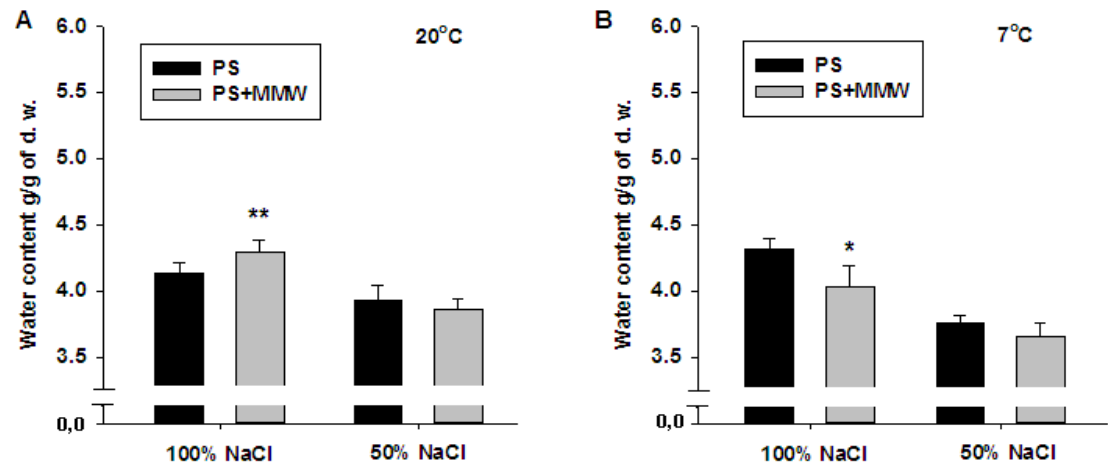

Fig. 3: Data of Water Content in Brain Cortex Tissues Incubated in $100 \%$ and $50 \%\left[\mathrm{Na}^{+}\right]_{\mathrm{O}}$ PS Compared with the Same Data of NT MW-Treated PS at $20^{\circ} \mathrm{C}(\mathrm{A})$ and $7^{\circ} \mathrm{C}(\mathrm{B})$ in Vitro Experiments. Ordinates Indicate the Mean Value of Water Content in Tissues (G/G of D.W.). Each bar Represents the Mean and \pm SEM for Three Independent Experiments. The Number of Slices of Cortex Is 120 . The Symbols $(*)$ and $(* *)$ Indicate $\mathrm{P}<0.05$ and $\mathrm{P}<0.01$, Respectively. The Number of Adult Animals Used for the Experiments Is 30.

Our earlier work has shown that $\mathrm{Ca}^{2+}$ contents in PS has an essential role in determination of magnetic sensitivity of physicochemical properties of PS [27], [28]. To check the role of $\mathrm{Ca}^{2+}$ in determination of NT MW effect on physicochemical properties of PS, having modulation effect on brain cortex hydration, the effect of NT MW-treated PS (where nonradioactive ${ }^{40} \mathrm{Ca}^{2+}$ was replaced by ${ }^{45} \mathrm{Ca}^{2+}$ isotope) on brain cortex hydration has been studied (Fig.4).

As ${ }^{45} \mathrm{Ca}^{2+}$ has $\beta$ radiation it is predicted that it should have more pronounced modulation effect on the structure of PS than ${ }^{40} \mathrm{Ca}^{2+}$ (non-radioactive). Fig. 4 shows that NT MW-treated PS containing ${ }^{45} \mathrm{Ca}^{2+}$ has pronounced dehydration effect on brain cortex tissue, while NT MW-treated PS containing nonradioactive ${ }^{40} \mathrm{Ca}^{2+}$ has hydration effect on brain cortex tissue. The study on the effect of IP injection of NT MW-treated PS on ${ }^{45} \mathrm{Ca}^{2+}$ uptake by cortex tissue has shown that the strong activation of ${ }^{45} \mathrm{Ca}^{2+}$ uptake (Fig. 5A) is accompanied by tissue dehydration (Fig. 5B).

Previously it has been shown that $10^{-9} \mathrm{M}$ ouabain, which activates $\mathrm{R} \mathrm{Na}^{+} / \mathrm{Ca}^{2+}$ exchange [30], stimulates rats' brain tissue hydration [29]. As it can be seen in Fig. 5A, NT MW-treated PS at $10^{-9} \mathrm{M}$ ouabain compared with the injection of sham-treated PS containing $10^{-9} \mathrm{M}$ ouabain, does not cause significant changes in ${ }^{45} \mathrm{Ca}^{2+}$ uptake, while at $10^{-4} \mathrm{M}$ ouabain NT MW-treated PS has activation effect on ${ }^{45} \mathrm{Ca}^{2+}$ uptake compared with sham one. Furthermore, the IP injection of NT MW-treated PS containing ${ }^{45} \mathrm{Ca}^{2+}$ both at ouabain-free and ouabain containing $\left(10^{-9} \mathrm{M}\right.$ and $\left.10^{-4} \mathrm{M}\right)$ mediums has dehydration effecton brain cortex tissue.

As it has been previously shown $10^{-9} \mathrm{M}$ and $10^{-4} \mathrm{M}$ ouabain increase brain cortex tissue hydration, while the effect of $10^{-9} \mathrm{M}$ ouabain is more pronounced than the effect of $10^{-4} \mathrm{M}$ ouabain (Fig. 5C) [29].

Our previous studies have demonstrated that $10^{-9} \mathrm{M}$ ouabain, which does not inhibit $\mathrm{Na}^{+} / \mathrm{K}^{+}$pump activity, stimulates ${ }^{45} \mathrm{Ca}^{2+}$ uptake in snail neurons by cAMP-dependent $\mathrm{R} \mathrm{Na}^{+} / \mathrm{Ca}^{2+}$ exchange [28], [30]. As intracellular cyclic nucleotides have a crucial role in regulation of $\mathrm{Ca}^{2+}$ homeostasis and intracellular signal transduction, the effects of IP injection of PS treated by NT MW on intracellular contents of cAMP and cGMP in brain cortex tissue have been studied in order to check their possible involvement in the increase of both cell hydration and ${ }^{45} \mathrm{Ca}^{2+}$ uptake. The data presented in Fig. 6 indicate that, like in case of nM ouabain [30], IP injection of NT MW-treated PS significantly elevates intracellular contents of both cAMP (in 38\%) and cGMP (in 12\%) in cortex tissue.

In order to find out whether $10^{-9} \mathrm{M}$ ouabain and NT MW-treated PS have a common metabolic target through which the modulation of cortex tissue hydration is realized, the effect of NT MW-treated PS on dose-dependent $\left[{ }^{3} \mathrm{H}\right]$-ouabain binding with cell membrane has been studied. The data presented in Table 1 indicate that NT MW-treated PS has strong inhibitory effect on $\left[{ }^{3} \mathrm{H}\right]$-ouabain binding with cell membrane at low concentrations $\left(10^{-9} \mathrm{M}-10^{-7} \mathrm{M}\right)$ compared with $10^{-4} \mathrm{M}$ ouabain (Table 1). 


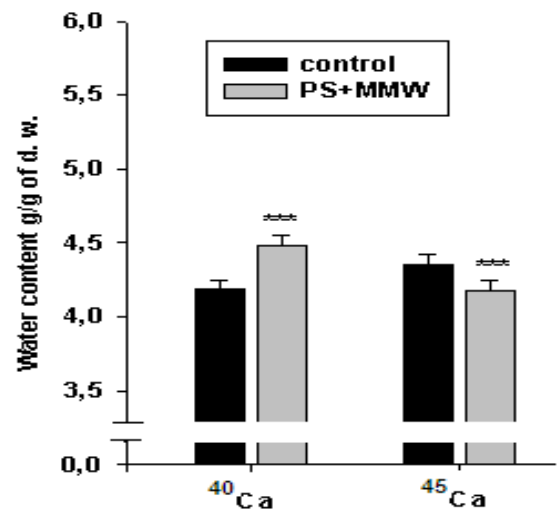

Fig. 4: ${ }^{45} \mathrm{Ca}^{2+}$ Uptake in Brain Cortex Tissues after IP Injection of NT MW-Treated PS. These Data are compared with those without any ${ }^{45} \mathrm{Ca}{ }^{2+}$ (the First Pair of Bars). Ordinates Indicate the Mean Value of Water Content in Tissues (G/G of D.W.). Each bar Represents the Mean and \pm SEM for Three Independent Experiments. The Number of Slices of Cortex Is 30. The Symbol (***) Indicates $\mathrm{P}<0.001$. The Number of Adult Animals Used in the Experiment Is 30 .
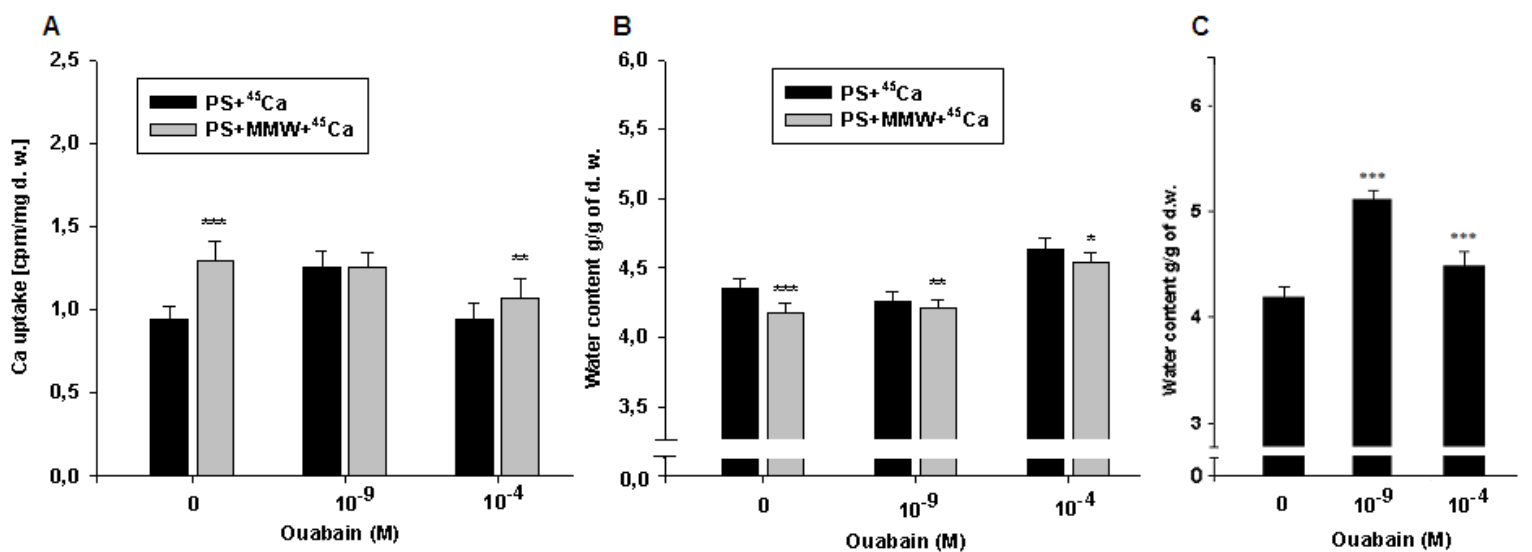

Fig. 5: ${ }^{45} \mathrm{Ca}^{2+}$ (A) and Water Content in Brain Cortex Tissues (B) Incubated in Ouabain-Free PS and NT MW-Treated PS at 10 $0^{-9} \mathrm{M}, 10^{-4} \mathrm{M}$ Ouabain. Water Content in Brain Cortex Tissues Incubated in Ouabain-Free PS and at $10^{-9} \mathrm{M}, 10^{-4} \mathrm{M}$ Ouabain Containing Non-Radioactive ${ }^{40} \mathrm{Ca}{ }^{2+}(\mathrm{C}) . \mathrm{Ordinates}$ on $(\mathrm{A})$ Indicate the Mean Value of ${ }^{45} \mathrm{Ca}^{2+}$. Ordinates on (B) and (C) Indicate the Mean Value of Water Content in Tissues (G/G of D.W.) Abscissas Indicate Ouabain Concentrations. Each bar Represents the Mean and ISEM for Three Independent Experiments. The Number of Slices of Cortex Is 120 . The Symbols $(*),(* *)$ and $(* * *)$ Indicate $\mathrm{P}<0.05, \mathrm{P}<0.01$ and $\mathrm{P}<0.001$, Respectively. The Number of Adult Animals Used in the Experiment Is 54 .

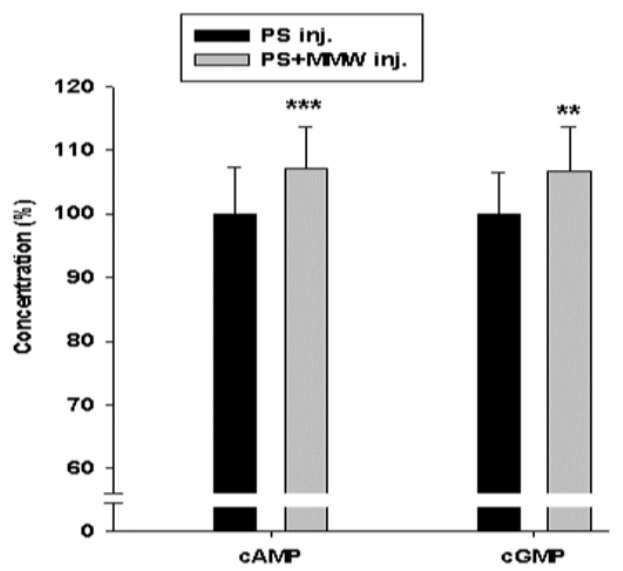

Fig. 6: The Effects of IP Injectionof Sham- (Black Columns) and NT MW-Treated (White Columns) PS on Inracellular Contents of cAMP (Left Columns) and cGMP (Right Columns) Contents in Brain Cortex Tissues. Ordinates Indicate the Mean and \pm SEM of Nucleotides. The Number of Cortex Slices Is 120 .The Symbols (**) and (***) Indicate $\mathrm{P}<0.01$ and $\mathrm{P}<0.001$, Respectively. The Number of Adult Animals Used in the Experiment Is 18 .

Table 1: $\left[{ }^{3} \mathrm{H}\right]-$ Ouabain Binding with Cell Membrane of Brain Cortex Tissues

\begin{tabular}{|c|c|c|c|c|c|}
\hline \multicolumn{6}{|c|}{ Number of ouabain molecules $\left[{ }^{*} 10^{8}\right]$} \\
\hline Brain zones & Ouab. doses & PS+ouab. & PS+ NT MW+ouab. & $\mathrm{p}$ & $\Delta(\%)$ \\
\hline \multirow{5}{*}{ ن্ট兀 } & $10^{-9}$ & $0.29 \pm 0.02$ & $0.25 \pm 0.02$ & $* \mathrm{p}<0.05$ & $11.7 \downarrow$ \\
\hline & $10^{-8}$ & $2.63 \pm 0.22$ & $2.32 \pm 0.17$ & $* * * \mathrm{p}<0.001$ & $11.9 \downarrow$ \\
\hline & $10^{-7}$ & $26.95 \pm 1.8$ & $24.16 \pm 1.78$ & $* * * \mathrm{p}<0.001$ & $10.4 \downarrow$ \\
\hline & $10^{-6}$ & $259.94 \pm 19.53$ & $239.07 \pm 16.43$ & $* * \mathrm{p}<0.01$ & $8.0 \downarrow$ \\
\hline & $10^{-4}$ & $2623.34 \pm 155.03$ & $2467.6 \pm 168.56$ & $\mathrm{p}>0.05$ & $5.9 \downarrow$ \\
\hline
\end{tabular}

Sham- (PS +ouabain) injection

Experiment- (PS+ NT MW) + ouabain injection 


\section{Discussion}

Water, being a dominant component of cells, is a common medium for intracellular reactions and has a determining role in cell metabolism. The increase of cell hydration stimulates the metabolic reactions by activation of intracellular macromolecules [31] and membrane proteins, having enzymes [27], receptors [32] and ionic channel forming properties [33] by surface-dependent changes of cell membrane.

It is known that in living cells intracellular osmotic pressure exceeds the extracellular one. As cell membrane is highly permeable for water molecules, the metabolically driven water efflux balances water uptake by cell [15], [16], [34]. In our previous study it has been shown that water influx through membrane has activation effect on $\mathrm{Na}^{+}$and $\mathrm{Ca}^{2+}$ inward currents, while water efflux from the cell has inactivation effect on them [33], [35]. Thus, the release of endogenous water molecules during oxidative processes in cells, besides activating cell metabolism by generation of water efflux through the membrane, has counteracting effect on gradient-driven $\mathrm{Na}^{+}$and $\mathrm{Ca}^{2+}$ influxes into cells

Taking into consideration the facts that water structure is extrasensitive to EMF [11], [36], [37] and cell membrane permeability for water is higher than for ions [16], [34] it is predicted that EMF-induced water influx through the membrane should precede the ionic one. Therefore, we have suggested that EMF-induced changes of thermodynamic activity of water on cell membrane, generating water fluxes through the membrane, could serve as a primary messenger through which the modulation of cell metabolic activity is realized [36], [37].

The data obtained in present study have shown that dosedependent ouabain effects on brain cortex tissue hydration are significantly changed upon the exposure of rats' head with NT MW (Fig. 1). These results clearly demonstrate that NT MW radiation is able to change the metabolic control of cell hydration in brain cortex tissue at different concentrations of ouabain.

The obtained data showing that NT MW radiation on rats at $10^{-11} \mathrm{M}$ ouabain leads to more pronounced dehydration effect on brain cortex than in case of sham animals (Fig. 1) allow us to consider the intracellular signaling system controlling cell hydration as a target for NT MW effect on brain cortex hydration.

The data demonstrating that IP injection of sham-treated PS leads to cortex tissue hydration in adult and dehydration in old rats and that IP injection of NT MW-treated PS has hydration effect in the same tissues of both ages of animals (Fig. 2) indicate that there are different mechanisms responsible for the stress (IP injection)induced and NT MW-induced tissue hydration. It is known that aging causes increase of $\left[\mathrm{Ca}^{2+}\right]_{\mathrm{i}}$ leading to the impairment of metabolic activity of neurons [38] which is accompanied by neuronal dehydration [39]. Therefore, stress-induced elevation of cortex tissue hydration in adult rats can be considered as a result of increase of metabolic activity leading to the release of water in cytoplasm, while elevation of cortex tissue hydration in old rats as a result of inhibition of metabolic activity of cells.

The data showing that IP injection of NT MW-treated PS has more pronounced hydration effect on brain tissue in both ages of animal groups than sham-treated PS (Fig. 2) support our working hypothesis, according to which NT MW-induced changes of physicochemical properties of cell aqua medium could serve as a primary messenger for NT MW effect on cortex tissue hydration.

The data that at $7^{\circ} \mathrm{C}$ medium (where cell metabolism is fully inhibited) the incubation of brain tissue samples in NT MWtreated PS leads to tissue dehydration (Fig. 3B), while at $20^{\circ} \mathrm{C}$ medium (Fig. 3A) (where cell metabolism in brain samples tissues is partly depressed compared to those in vivo state, Fig. 2) NT MW-treated PS has hydration effect, allow us to suggest that the hydration effect of NT MW-treated PS in vivo experiments has a metabolic nature. However, the mechanism(s) responsible for this effect, which has age-dependent increasing character, needs to be elucidated.
The crucial role of $\mathrm{Ca}^{2+}$ in realization of biological effects of NT MW has been established since the works of Prof. Adey [2] and Prof. Blackman [40], [41]. Later, it was shown that $\left[\mathrm{Ca}^{+2}\right]_{\mathrm{i}}$ is increased upon the impact of NT MW. This was explained by NT MW-induced activation of potential dependent- $\mathrm{Ca}^{2+}$ channels [41], [42]. However, it is known that for the activation of potential-dependent ionic channels there is a need for depolarization of the membrane by couple of $\mathrm{mV}$ 's, which energy is much higher than the energy of NT MW. Therefore, the explanation of NT MW-induced increase of $\left[\mathrm{Ca}^{2+}\right]_{\mathrm{i}}$ by activation of potentialdependent $\mathrm{Ca}^{2+}$ channels seems unreliable. The next mechanism through which $\mathrm{Ca}^{2+}$ uptake takes place is cAMP-activated $\mathrm{R}$ $\mathrm{Na}^{+} / \mathrm{Ca}^{2+}$ exchange, which is sensitive even to $\mathrm{nM}$ concentrations of biologically active substances, such as synaptic transmitters and ouabain [43], [44].

The data of in vitro experiments where $50 \%\left[\mathrm{Na}^{+}\right]_{\mathrm{o}}$ PS (which activates $\mathrm{R} \mathrm{Na}^{+} / \mathrm{Ca}^{2+}$ exchange)leads to brain tissue dehydration at $20^{\circ} \mathrm{C}$ (Fig. 3A) and is elevated by NT MW-treated PSallow us to consider the stimulation effect of NT MW-treated PS on tissue hydration as a result of activation of $\mathrm{R} \mathrm{Na}^{+} / \mathrm{Ca}^{2+}$ exchange. This suggestion is supported by the data on the study of the effect of NT MW-treated PS on ${ }^{45} \mathrm{Ca}^{2+}$ uptake (Fig 5).

The fact that in vivo experiment IP injection of PS containing ${ }^{45} \mathrm{Ca}^{2+}$ having $\beta$ radiation increases brain tissue hydration, like in case of the effect of NT MW-treated PS containing ${ }^{40} \mathrm{Ca}^{2+}$ (Fig. 4), indicates that even low ionizing radiation, which changes the physicochemical properties of cell aqua medium, has an impact on ${ }^{45} \mathrm{Ca}^{2+}$ uptake. However, the facts that IP injection of NT MWtreated PS containing ${ }^{45} \mathrm{Ca}^{2+}$ has dehydration (Fig. 5) effect on brain cortex tissue, while IP injection of NT MW-treated PS containing ${ }^{40} \mathrm{Ca}^{2+}$ has hydration (Fig. 2) effect indicate that there are different mechanisms responsible for these two effects on brain tissue hydration.

The results obtained from the experiments of the present work showing that NT MW-treated PS has statistically significant activation effect on ${ }^{45} \mathrm{Ca}^{2+}$ uptake both in cases when $\mathrm{Na}^{+} / \mathrm{K}^{+}$pump is in active (ouabain-free medium) and in inactive states (in $10^{-4} \mathrm{M}$ ouabain) indicate that NT MW-induced activation of ${ }^{45} \mathrm{Ca}^{2+}$ uptake does not depend on $\mathrm{Na}^{+} / \mathrm{K}^{+}$pump activity (Fig. 5A). Previously it has been shown that $10^{-9} \mathrm{M}$ ouabain which has activation effect on $\mathrm{R} \mathrm{Na}^{+} / \mathrm{Ca}^{2+}$ exchange in neurons is accompanied by the increase of intracellular cAMP contents [30]. It has also been shown that $10^{-}$ ${ }^{9} \mathrm{M}$ ouabain has strong hydration effect on rats' brain cortex and heart muscle tissues and this effect has age-dependent reverse character due to $\mathrm{R} \mathrm{Na}^{+} / \mathrm{Ca}^{2+}$ exchange activation [39]. The data that IP injection of NT MW-treated PS at $10^{-9} \mathrm{M}$ ouabain has no activation effect on ${ }^{45} \mathrm{Ca}^{2+}$ uptake (Fig. 5A) compared with shamtreated PS indicate that the stimulation of ${ }^{45} \mathrm{Ca}^{2+}$ uptake by both NT MW-treated PS and $10^{-9} \mathrm{M}$ ouabain is realized by the same mechanism, i.e by $\mathrm{R} \mathrm{Na}^{+} / \mathrm{Ca}^{2+}$ exchange. As $\mathrm{R} \mathrm{Na}^{+} / \mathrm{Ca}^{2+}$ exchange functions in stoichiometry of $3 \mathrm{Na}^{+}: 1 \mathrm{Ca}^{2+}$ it is predicted that its activation should lead to brain tissue dehydration. The data that the activation of ${ }^{45} \mathrm{Ca}^{2+}$ uptake by both $10^{-9} \mathrm{M}$ ouabain and NT MW-treated PS containing ${ }^{45} \mathrm{Ca}^{2+}$ is not accompanied by the activation of cell hydration, while NT MW-treated PS containing $10^{-9} \mathrm{M}$ ouabain $+{ }^{40} \mathrm{Ca}^{2+}$ activates ${ }^{45} \mathrm{Ca}^{2+}$ uptake and is accompanied by cell hydration allows us to suggest that NT MWinduced cell hydration, which depends on metabolism, is not a direct result of the increase of $\left[\mathrm{Ca}^{2+}\right]_{\mathrm{i}}$.

Therefore, we suggest that the increase of intracellular cAMP contents upon the impact of both $10^{-9} \mathrm{M}$ ouabain and NT MWtreated PS injections could be a reason for the changes of brain tissue hydration.

This suggestion is supported by the data presented in Fig. 6 showing that NT MW-treated PS increases cAMP contents. The fact that NT MW-treated PS also increases cGMP contents can be explained by the activation of $\mathrm{R} \mathrm{Na}^{+} / \mathrm{Ca}^{2+}$ exchange bringing to the increase of $\left[\mathrm{Ca}^{2+}\right]_{\mathrm{i}}$ which in its turn swiches on "Cacalmodulin-NO- cGMP formation" cascade [42], [45]. 
The data that NT MW-treated PS has inhibitory effect on $\left[{ }^{3} \mathrm{H}\right]-$ ouabain binding with cell membrane which is more pronounced at $10^{-9}-10^{-7} \mathrm{M}$ ouabain compared with higher concentrations (Table 1) support our suggestion that the activation of cAMP-dependent $\mathrm{R} \mathrm{Na}^{+} / \mathrm{Ca}^{2+}$ exchange is the common signalling system through which the effects of NT MW-treated PS at $10^{-9} \mathrm{M}$ ouabain on cell hydration is realized.

Thus, on the basis of the obtained data it can be concluded that NT MW radiation changes physicochemical properties of skin and sub skin water contents, which in its turn leads to the activation of $\mathrm{R}$ $\mathrm{Na}^{+} / \mathrm{Ca}^{2+}$ exchange. The latter is accompanied by the increase of intracellular contents of cAMP in healthy (young) animals, and leads to cell hydration which is a result of stimulation of oxidative processes-induced release of endogenous $\mathrm{H}_{2} \mathrm{O}$. Whereas, in nonhealthy (old) animals the cAMP-dependent activation of oxidative processes is in a dysfunctional state and NT MW radiation leads to neuronal dehydration because of the activation of $\mathrm{R} \mathrm{Na}^{+} / \mathrm{Ca}^{2+}$. As $\mathrm{Ca}^{2+}$ has multisided poisoning effect on neurons, we suggest that NT MW radiation serves as a potential factor leading to the brain functional impairment, especially when brain metabolic activity is depressed (e.g. during aging).

\section{Acknowledgement}

We express our gratitude to Ani Gyurjinyan and Anna Sargsyan from UNESCO Chair in Life Sciences for editorial work.

\section{References}

[1] N.D. Devyatkov, Effect of a SHF (mm-band) radiation on biological objects, UspekhiFizicheskikhNauk 110 (1973) 453-454 (in Russian).

[2] W.R. Adey, Tissue interactions with non-ionizing electromagnetic field, Physiol. Rev. 61 (1981) 435-514.

[3] N.D. Devyatkov, M.B. Golant, O.V. Betsky, Millimeter waves and their role in the processes of life, Radio i Svyaz (1991) (in Russian).

[4] M.C. Ziskin, Physiological mechanisms underlying millimeter wave therapy, Bioelectromagnetics Current Concepts, Springer, Netherlands, 2006; 241-251.http://dx.doi.org/10.1007/1-40204278-7 14.

[5] M. Markov, Benefit and hazard of electromagnetic fields,Electromagnetic Fields in Biology and Medicine: CRC Press, $2015 ; 15-28$.

[6] BioInitiative Working Group Report WHO, A Rationale for Biologically-Based Public Exposure Standards for Electromagnetic Radiation. Sage C, Carpenter DO, eds, 2012. Available from: www. bioinitiative.org

[7] H. Lai, Genetic effects of non-ionizing electromagnetic fields, BioInitiative , 2014, suppl. 6 Available from: www. bioinitiative.org

[8] V.N. Binhi, A.B. Rubin, The kT paradox and possible solutions, Electromagnet. Biol. Med.26 (2007) 45 62.http://dx.doi.org/10.1080/15368370701205677.

[9] A. Belyaev, Evidence for disruption by modulation role of physica and biological variables in bioeffects of non-thermal microwaves for reproducibility, cancer risk and safety standards, BioInitiativeWorking Group 2012, 15.

[10] S.F. Barnes, B. Greenebaum, The effects of weak magnetic fields on radical pairs, Bioelectromagnetics, $36 \quad$ (2015) 45 54.http://dx.doi.org/10.1002/bem.21883.

[11] V.I. Klassen, Magnetized water systems. Chemistry Press, 1982, 296 (In Russian)

[12] M.F. Chaplin, Information Exchange within Extracellular Water. In Pollack, G. et al. eds. Water and the Cell, the Netherlands, Springer, 2006, 113-123.http://dx.doi.org/10.1007/1-4020-4927-7_5.

[13] S.N. Ayrapetyan, E. Dadasyan, G. Ayrapetyan et al., the Nonthermal Effect of Weak Intensity Millimeter Waves on Physicochemical Properties of Water Solutions. Electromagnetic Biology and Medicine, $28 \quad$ (2009) 341.http://dx.doi.org/10.3109/15368370903206531.

[14] A. Deghoyan, A. Heqimyan, A.Nikoghosyan et al., Cell bathing medium as a target for non-thermal effect of millimeter waves, Electromagnetic Biology and Medicine 31 (2012) 132-142. http://dx.doi.org/10.3109/15368378.2011.624659.

[15] M. Borgnia, S. Nielsen,A. Engel et al., Cellular and molecular biology of the aquaporin water channels, Annual Review of Biochemis- try

68(1999)

425

458.http://dx.doi.org/10.1146/annurev.biochem.68.1.425.

[16] E.K. Hoffman, B.H. Sorensen, D.P. Sauter, I.H. Lambert, Role of volume-regulated and calcium-activated anion channels in cell volume homeostasis, Cancer and Drug resistance, Channels, (Austin) 9 (2015) 380-396.http://dx.doi.org/10.1080/19336950.2015.1089007.

[17] R.Simonyan, A. Ghulyan, S. Ayrapetyan,High-Frequency Device for the Measurement of specific Absorption Rate of Biotissues of High Intensity. In: Bioelectromagnetics: Current Concepts, S. Ayrapetyan and M. Markov, eds., NATO Science Series, Springe Press, the Netherlands, 2006, 291-296.http://dx.doi.org/10.1007/1 4020-4278-7_18.

[18] K. Krnjevic, Cellular and synaptic actions of general anaesthetics, Gen Pharmacol 23 (1992) 965-75. http://dx.doi.org/10.1016/0306 3623(92)90274-N

[19] A.Heqimyan, A. Deghoyan, S. Ayrapetyan, Ketamine-induced cell dehydration as a mechanism of its analgesic and anesthetic effects,J Int Dent Med Res 4 (2011) 42-49.

[20] R. Takahashi, M. Aprison, Acetylcholine content of discrete areas of the brain obtained by a near-freezing method, J chem11 :(1964) 887-898.

[21] R.H. Adrian, The effect of internal and external potassium concentration on the membrane potential of frog muscle, JPhysiol 133 (1956) 631-658.http://dx.doi.org/10.1113/jphysiol.1956.sp005615.

[22] M.P. Blaustein, W.J.Blaustein, $\mathrm{Na}+/ \mathrm{Ca} 2+$ exchange. Its physiological implications, Physiol Rev 79 (1999)763-854.

[23] Z. Xie, A. Askari,Na+/K+-ATPase as a signal transducer, Eur J Biochem 269 (2002) 2434-2439. http://dx.doi.org/10.1046/j.14321033.2002.02910.x.

[24] F. Lang, E.K. Hoffmann, Cell role of ion transport in control of apoptotic cell death, Comp Physiol 2 (2012 2037-61. Available from: http://dx.doi.org/10.1002/cphy.c110046.

[25] A.L.Lehninger, Mitochondria and calcium ion transport, Biochem J 119 (1970) 129-138.http://dx.doi.org/10.1042/bj1190129.

[26] P.F. Baker, M.P.Blaustein, A.L. Hodgkin, S.A. Steinhardt, The influence of calcium on sodium efflux in squid axons, J Physiol 200 (1969)431-458. http://dx.doi.org/10.1113/jphysiol.1969.sp008702.

[27] S.N. Ayrapetyan, M.A. Suleymanyan, A.A. Sagian, S.S. Dadalyan, Autoregulation of electrogenic sodium pump, CelMolNeurobiol 4 (1984a) 367-384.http://dx.doi.org/10.1007/bf00733598.

[28] S.N. Ayrapetyan, Kh.V. Stamboltsyan, M.A. Sulemanyan, On the Discrete Character of Change of Helix Snail Neuron Volume in Solutions of Different Tonicity, DoklAkadNauk SSSR 278 (1984b) 1238- 1240.

[29] A. Heqimyan, L. Narinyan,A. Nikoghosyan, S. Ayrapetyan, Agedependent magnetic sensitivity of brain and heart muscles, Electromagnetic Fields in Biology and Medicine, M. Markov ed. USA: CRC Press, 2015, 217-230.

[30] A.A. Saghian, S.N. Ayrapetyan, D.O.Carpenter, Low dose of ouabain stimulates the $\mathrm{Na} / \mathrm{Ca}$ exchange in neurons, Cell MolNeurobiol 16 (1996)489-498.http://dx.doi.org/10.1007/BF02150229.

[31] V.A. Parsegian, R.P. Rand, D.C. Rau, Osmotic stress, crowding, preferential hydration and binding: A comparison of perspectives USA: Proc Nat Sci97(2000) 3987-3992. Pharmaceuticals http://dx.doi.org/10.3390/ph8040675

[32] S.N. Ayrapetyan, V.L. Arvanov, on the mechanism of the electrogenic sodium pump dependence of membrane chemosensitivity, Comp BiochemPhysiol, $64 \quad$ (1979) 601-604 http://dx.doi.org/10.1016/0300-9629(79)90592-9.

[33] S.N. Ayrapetyan, G.Y. Rychkov, M.A. Suleymanyan, Effects of water flow on transmembrane ionic currents in neurons of Helix pomatia and in Squid giant axon, Comp BiochemPhysiol, 89 (1988) 179-186.

[34] S.F. Pedersen, Y. Okada, B. Nilius, Biophysics and Physiology of the Volume-Regulated Anion Channel (VRAC)/Volume-Sensitive Outwardly Rectifying Anion Channel (VSOR), Pflugers Arch 468 (2016) 371-83.http://dx.doi.org/10.1007/s00424-015-1781-6.

[35] M. Kojima, S. Ayrapetyan, K. Koketsu, On The Membrane Potential Independent Mechanism of Sodium Pump-Induced Inhibition of Spontaneous Electrical Activity of Japanese Land Snail Neurons, Comp. Biochem. Physiol. $77 \quad$ (1984) 577-583. http://dx.doi.org/10.1016/0300-9629(84)90232-9.

[36] S.N. Ayrapetyan, A.S. Avanesian, T.H. Avetisianet al.,Physiological Effects of Magnetic Fields may be mediated through Actions on the State of Calcium Ions in Solution. In: D. Carpenter and S. Ayrapetyan (eds.), Biological Effects of Electric and Magnetic Fields: Volume 1, Academic Press, 1994; 181 192.http://dx.doi.org/10.1016/B978-0-12-160261-1.50012-2.

[37] S. Ayrapetyan, N. Baghdasaryan, Y. Mikaelyan, S. Barseghyan, V. Martirosyan, A. Heqimyan, L. Narinyan, A. Nikoghosyan, Cell 
bathing medium as a primary target and cell hydration as a universal biomarker for biological effects of non-ionizing radiation. In Prof. Marko S. Markov (eds): Electromagnetic Fields in Biology and Medicine, CRC Press, 2015; 193-216.

[38] Z.S. Khachaturian, The role of calcium regulation in brain aging: reexamination of a hypothesis, Aging (Milano), 1 (1989) 17-34. http://dx.doi.org/10.1007/BF03323872.

[39] A.Nikoghosyan, A.Heqimyan, S. Ayrapetyan, Primary mechanism responsible for age-dependent neuronal hydration, Intern $\mathrm{J}$ Basic $\begin{array}{lllll}\text { Applied } & \text { Sci } & 5 & \text { (2016) }\end{array}$ 14.http://dx.doi.org/10.14419/ijbas.v5i1.5388.

[40] C.F. Blackman, S.G. Benane, J.R. Rabinowitz, A role for the magnetic field in the radiation-induced efflux of calcium ions from brain tissue in vitro, Bioelectromagnetics 6 (1985) 327337.http://dx.doi.org/10.1002/bem.2250060402.

[41] C.F. Blackman, S.G. Benane, D.J. Elliott,Influence of electromagnetic fields on the efflux of calcium ions from brain tissue in vitro: a three-model analysis consisted with the frequency response up to $510 \mathrm{~Hz}, \quad$ Bioelectromagnetics 9 (1988) 215227.http://dx.doi.org/10.1002/bem.2250090303.

[42] K.V. Azatian, A.R. White, R.J. Walker, S.N. Ayrapetyan, Cellular and molecular mechanisms of nitric oxide-induced heart muscle relaxation, Gen. Pharmac 30 (1998) 543553.http://dx.doi.org/10.1016/S0306-3623(97)00302-9.

[43] S.N. Ayrapetyan, D.O. Carpenter, Very Low Concentration of Acetylcholine and GABA Modulate Transmitter Responses, Membrane and Cellular Biophysics and Biochemistry NeuroReport (1991) 563-565.

[44] S. Ayrapetyan, Cell hydration as a Universal Marker for Detection of Environmental Pollution, Environmentalist J. (2012) 210-221.

[45] M. Brini, E Carafoli, Calcium pumps in health and disease, Physiol. Rev $89 \quad$ (2009) 13411378.http://dx.doi.org/10.1152/physrev.00032.2008. 